\title{
Executing Public Notary Officials Role In Making Cooperative Agreement
}

\begin{abstract}
Fani Pratama ${ }^{1}$ and Akhmad Khisni ${ }^{2}$
Abstract. True cooperative is a business entity that stands based on family rules, in Indonesia cooperative stand up and walk before the independence of Indonesia. First it was a banking company in Purwokerto, Central Java founded by Raden Aria Wiria Atmadja aided and forwarded by a Resident De Wolf Van Westerorde using cooperative system is not running because it is considered more pro natives. Trip the cooperative development of the pre and postindependence Indonesia severely affected the economy of Indonesia. Development side by side with other economic system, cooperatives perceived need of the legality of the law in all of their business activities. The legality of a cooperative is the agreement of establishment of cooperatives. A public official who has the authority to make the authentic act is a notary.

Keywords: Cooperative, Agreements, Notary.
\end{abstract}

\section{Introduction}

A cooperative form of business entity reflects the economic development of the nation of Indonesia. In it contains many of the values of Pancasila. The development of the cooperative was considered worthy legal certainty, to meet the cooperative propriety required documents, letters as supporting documents of the absolute. The documents or letters let be made and before someone or officers, person or official who is a public notary purpose.

Public notary officials who are authorized to make authentic agreement and have more authority as referred to in this Act or under any other laws ${ }^{3}$. Public notary officials which can be said to serve the general public or specific public in the field of civil law. With his powers and functions able to guarantee in terms of legal force, testimonies trustworthy does not favor one party and advisors without blemish, intervention and make arrangements to protect in the days to come ${ }^{4}$.

The establishment of a body cooperative need, use and use of notarization, which meant notarial agreement pursuant to Article paragraph (1) of Act No. 2 on Amendment No. 30 of 2004 concerning Notary as follows:

"Notary Agreement the become authentic agreement is an agreement made by or before a Notary according to the forms and procedures stipulated in this law and is described in the explanation Notary Act (UUJN) No. 2 of 2014 on the Amendment of Act No. 30 of 2004 concerning Notary in Article 15 (1) reads: "Notary authorized to make the authentic act of all acts of the agreement, and the stipulation that must be done by legislation and or desired by the stakeholders to be stated in an authentic agreement, guaranteeing the creation date of the agreement, saving certificates, giving grose, copy, and official copies, all of it throughout the making of the agreement

\footnotetext{
${ }^{1}$ Student of Master Program in Notary Program UNISSULA email fanipratama2016@gmail.com

2 Lecturer of Faculty of Law UNISSULA

${ }^{3}$ Act No. 2 of 2014 on amandement of Act No. 30 of 2004 on Notary.

4 Tan Thong Kie " Studi Notariat : Beberapa Mata Pelajaran Dan Serba Serbi Pratek Notaris

Buku I" PT. Ichiar Baru Van Hoeve Jakarta p.162
} 
it not also be assigned or excluded to other officials or other person designated by the Act"5.

An authentic agreement has properties or criteria as an evidentiary tool, the shape is set in legislation and made before a Public Officer as a notary. In this case a legal regulation of protection for the cooperative and administrators in performing all activities of cooperative efforts in the future.

The authentic act is formed from an official who is authorized to it, it comes under the provisions of Article 1868 Book of Civil Law whose contents are: "An authentic agreement of an agreement in the form prescribed by the Act, made by or before the Public Officials of the ruling to it where the agreement was made"

According to Article 1 (4) Decree of the Minister of Cooperatives and Small and Medium Enterprises of the Republic of Indonesia No. 98 / KEP / M KUKM / IX / 2004 About Notary Agreement For Cooperative, says that understanding Cooperation Agreement Notary is:

"Public officials appointed under Rule Position otaris by other power to make incorporation agreement, agreement of amendment of the basic budget and other agreements related to the activities of the Cooperative".

Decree of the Minister of Cooperatives and Small and Medium Enterprises of the Republic of Indonesia No. 98 / KEP / M KUKM / X / 2004 Concerning Cooperation Agreement Notary As, then set Notary as Cooperation Agreement Official, it is defined in Article 2 paragraph (1) which states that:

"Notary agreement Cooperative serves as the parties work by a code of ethics office and provide services to the community in the establishment, changes in the constitution and other agreements relating to cooperative activities".

Matters relating to the requirements of one of them are about the agreement. Notary Agreement or hereinafter called the agreement is the agreement made by the officials authorized to do so by the authorities in accordance with the conditions set either with or without the assistance of the parties concerned, the notes or requests, to set forth therein by the parties concerned. The authentic act contains an official statement which describes what is done or seen 6 .

The existence of a notary very have a role in aspects of community life, because in coeducating the nation through participation in development, because that is required for the notary to provide services legal counseling to the community in an effort to legal awareness, so that people are aware of and appreciate the rights and its obligations as a citizen and member of the people ${ }^{7}$.

The involvement of a public notary in this case not as a mere burden for the cooperative and the board, but aims to position the stronger cooperative with proof certificate of incorporation of cooperatives made by notary.

\section{Research Methods}

The method used in this research is normative juridical approach. Normative research is the approach taken by the primary legal materials by means of studying the theories, concepts, principles of law as well as legislation related to this research. This

\footnotetext{
5 Indonesia Legal Center Publishing " Himpunan Peraturan Perundang-undangan Jabatan " Notaris Dan PPAT CV. Karya Gemilang Jakarta p.2.

${ }^{6}$ Husni Thamrin Pembuatan Akta Pertanahan Oleh Notaris Laksbang Pressindo Yogyakarta p.11

7 Ignatius Ridwan Widyadharma 1994Hukum Profesi Tentang Propesi Hukum CV. Ananta Jakarta p. 133-134
} 
approach is also known by the literature approach, by studying books, legislation and other documents related to the research lot $^{8}$.

The formulation of the problem is how the role of the notary in the making of the agreement of establishment of cooperatives?; What is the function of the agreement of establishment of cooperatives for notary?; and What are the obstacles and solutions that are confronted notaries in cooperative agreement?

\section{Result And Discussion}

\subsection{Notary Role In The Making Of The Agreement Of Establishment Of Cooperatives}

Act No. 2 of 2014 on the Amendment to Act No. 30 of 2004 regarding Notary made formula of the authority of notaries who are already contained in Article 15 (1) No. 2 of 2014 on the Amendment to Act No. 30 of 2004 on Positions public notary:

"Notary authorized to make the authentic agreementity of all agreements, and determination required by legislation and/or desired by the stakeholders to be stated in the authentic agreement, guaranteeing the creation date of the agreement, save agreement, giving grosse, copy and quote agreement all of it along the agreement of making it not also be assigned or excluded to other officials or any other person specified by law."

Notary agreement before making an agreement of cooperatives that engage in advocacy or legal education that is general or public agreement relating to cooperatives. Notary as well as meeting minutes or records of the establishment of cooperative written by the notary will be poured into the agreement of establishment of cooperatives, as in the Minister of Cooperatives and Small and Medium Enterprises of the Republic of Indonesia No. 10 / Per / M.KUKM / IX / 2015 About Institutional Cooperative Article 4 (4) reads as follows: "Notary referred to in paragraph (3) noted principal the principal results of the discussion were agreed at a meeting of establishment to be formulated in the agreement. "

\section{- As a Public Notary Officials}

The basis for determining the notary as a public official has been implicit in the Act No. 2 of 2014 concerning Notary Article 1 number 1 in it mention that the notary is a public official who is authorized to make the authentic agreement and have the other authorities referred to in this Act or under other laws.

Other powers are also notary to certify the signatures and establish certainty letter under the hand as well as register in a special book, posted a note under the hand, make a copy of the original letter under the hand in the form of a copy that contains a description as written and depicted in the letter are concerned, approve their photos copy (notarized), provides legal counseling tekait with an agreement, an agreement of land as well as an agreement the minutes of the auction.

General officers attached to the notary is a form of a service to the general public in terms of making diverse or many kinds of certificates authentically related to the legal field kepedataan and this authority has not been delegated to other officials and asked by the general public who need or interest that a legal act they are expressed in the form of authentic agreement and the law require in the form of an authentic agreement whose authority was the notary.

\footnotetext{
8 Ibid.
} 


\section{- As a Public Notary Cooperation Agreement Official}

Notary agreement must meet the requirements as stated in the Decree of the Minister of Cooperatives and Small and Medium Enterprises of the Republic of Indonesia Number 98 / Kep / M.KUKM / IX / 2004 concerning the notary as Cooperation Agreement Chapter III Requirements and Procedures for the Determination of Notary Agreement cooperative Article 4: "To be in charge as a notary agreement cooperatives, must meet Google's Terms as follows:

- Notary who is authorized to run a notary office in accordance with the position.

- A certificate of proof has followed debriefing in the field of cooperatives which was signed by the minister.

Briefing or training notary agreement cooperative was organized by the Ministry of Cooperatives and Small and Medium Enterprises of the Republic of Indonesia in coordination with the Indonesian Notary Association or Universities or Private held Program is the study of Notary or can be held Indonesian Notary Association and Universities or Private held pogram Notary studies and acknowledged by the Deputy Minister of Institutional Aims to provide knowledge regarding cooperatives in Indonesia.

The requirements to become a notary agreement of cooperatives in the Minister of Cooperatives and Small and Medium Enterprises of the Republic of Indonesia Number 98 / Kep / M.KUKM / IX / 2004 about public notary as Cooperation Agreement Chapter III Requirements and Procedures for the Determination of Notary Agreement Cooperative Article 5 paragraph (1) as follows:

"Notaries who are qualified as referred to in Article 4 shall submit a written application to the Minister, through the head of the Department / Institution in charge of the cooperative district / city level in the seat of notary would be determined as a notary agreement Cooperative, by attaching;

- Notary Appointment Decree

- Certificate of proof has followed debriefing in the field of cooperatives

- Office address along with examples of signatures, initials and stamp sample Notary.

Notaries who are qualified, submit a written application addressed notary Deputy Minister cc Institutional accompanied by:

- Notary Appointment Decree stipulated by the Ministry of Justice and Human Rights of the Republic of Indonesia;

- Certificate of proof has followed a briefing in the field of Cooperatives;

- Office address along with examples of signatures, initials and stamp Notary.

Notary registration to become a notary agreement for today's cooperative can be made online through the official website.

\subsection{The Function Of The Agreement Of Establishment Of Cooperatives For Notaries}

The function of the cooperative establishment agreement made by the notary is a condition for the existence of something (formlitatis causa). The intention is to complete or perfect a legal act, it should be an agreement. Here the agreement is a formal requirement for the presence of something, in other words without the agreement then there is no state law or legal relationship. Here the notarial agreement is a requirement for the cooperative. So for the cooperative could be incorporated, one of the conditions is that the cooperative must attach a certificate of incorporation of cooperatives were created by a notary. 


\subsection{Obstacles And Solutions That Confronted Notaries In Agreement Cooperative}

- Obstacles faced by the Notarial Agreement of Establishment In The Development Cooperation.

- Implementation of this extension is sometimes not in accordance with the provisions for the attendance does not comply with the various reasons that often occur cancellation counseling.

- The supporting data or requirements for the preparation of the agreement of establishment of cooperatives, among others identity of the founders of the cooperative members and not in accordance with the domicile or does not apply.

- $\quad$ There is a disturbance in the system SISMINBHKOP (Legal Administration Entity Cooperatives System) that can print the legalization by the change of position in the Ministry of Cooperatives and SMEs of the Republic of Indonesia which is responsible SISMINBHKOP (Legal Administration Entity Cooperatives System) without giving any prior notice to the legalization proposed the establishment of cooperatives that can not be printed directly even for months.

- How to Overcome Obstacles faced by the Notarial Agreement of Establishment In The Making Cooperative

- Agreement of incorporation of a cooperative before it is made by a notary one of which is the extension of the cooperative. Counseling regarding cooperatives run smoothly according to schedule or time is determined when the adjusted time that if all members of the cooperative or counseling participants to attend counseling. Invite counseling is important and can not be represented to ensure all members of the cooperative or counseling participants.

- Population Identification Number (PIN) between the members there are limits to the enactment already be attempted due time created a Certificate issued and signed by the Head Office of Population and Civil Registration district or city.

- Coordination penyelusuran inhibition of printing the legalization of the establishment of a cooperative with staff allow the ministry of the Republic of Indonesia. If it does not give the notary agreement cooperative solutions come directly to the Ministry of Cooperatives and SMEs of the Republic of Indonesia Deputy Section Institution at JI. HR Rasuna Said Kav. 3-4, South Jakarta 12940 to request information and clarity as well as printing invoke the legalization of the establishment of cooperatives concerned.

\section{Closing}

\subsection{Conclusion}

- The role of the notary in the agreement of establishment of cooperatives among other things is an agreement officials of cooperatives, in the process of making cooperative founder notarial agreement act as advocate or legal counselor as well as the minutes of the meeting the formation of cooperatives. With authority as a public notary officials also acts as a public official who serves the interests of the public notary stand independently.

- The function of the cooperative establishment agreement made by the notary is a condition for the existence of something (formlitatis causa). The intention is to 
complete or perfect a legal act, it should be an agreement. Here the agreement is a formal requirement for the presence of something, in other words without the agreement then there is no state law or legal relationship. Here the notarial agreement is a requirement for the cooperative. So for the cooperative could be incorporated, one of the conditions is that the cooperative must attach a certificate of incorporation of cooperatives were created by a notary.

- Obstacles and solutions that confronted Notaries in agreement cooperative

- Obstacles faced by the Notarial Agreement of Establishment

- How to Overcome Obstacles faced by the Notarial Agreement of Establishment In The Development Cooperation.

\subsection{Suggestion}

For those who will make the notary agreement of establishment of cooperatives should carry out socialization and advocacy among the founders of the cooperative regarding the importance of cooperative extension. Cooperative Extension is pre procedures carried out before making the agreement of establishment of cooperatives, because the contents of the agreement of establishment of cooperatives is the result of the meeting noted the formation of the cooperative establishment notary who performed together in counseling and provide information relating to the formation and establishment of cooperatives clearly and precisely.

\section{Bibliography}

[1] Act No. 2 of 2014 on amandement of Act No. 30 of 2004 on Notary.

[2] Husni Thamrin Pembuatan Akta Pertanahan Oleh Notaris Laksbang Pressindo Yogyakarta.

[3] Ignatius Ridwan Widyadharma 1994 Hukum Profesi Tentang Propesi Hukum CV. Ananta Jakarta.

[4] Indonesia Legal Center Publishing "Himpunan Peraturan Perundang-undangan Jabatan" Notaris Dan PPAT CV. Karya Gemilang Jakarta.

[5] Regulation of the Minister of Cooperatives and Small and Medium Enterprises of the Republic of Indonesia Number: 10 / Per / M.KUKM / IX / 2015 About Institutional Cooperation

[6] State Minister of Cooperatives and Small and Medium Enterprises of the Republic of Indonesia No. 98 / KEP / M.KUKM / XI / 2004 Concerning Cooperation Agreement Official Notary

[7] Tan Thong Kie Studi Notariat : Beberapa Mata Pelajaran Dan Serba Serbi Pratek Notaris Buku I PT. Ichiar Baru Van Hoeve Jakarta. 